\title{
A pelagic myodocopid ostracod from the Silurian of Arctic Russia
}

\author{
VINCENT PERRIER $^{1 *}$, OLGA K. BOGOLEPOVA ${ }^{2}$, ALEXANDER P. GUBANOV $^{3}$, DAVID J. SIVETER ${ }^{1}$ \& MARK WILLIAMS ${ }^{1}$ \\ ${ }^{1}$ Department of Geology, University of Leicester, University Road, Leicester LE1 7RH, UK \\ ${ }^{2}$ CASP, Cambridge University, 18a Huntingdon Road, Cambridge CB3 0DH, UK \\ ${ }^{3}$ Museum of Evolution, Uppsala University, Norbyvägen 16, 752 36, Uppsala, Sweden \\ *Corresponding author (email: vp110@leicester.ac.uk)
}

\begin{abstract}
The Silurian myodocope ostracod Richteria migrans is reported from Arctic Russia, from Kotel'ny Island (New Siberian Islands) and the Taimyr Peninsula in strata of Ludfordian (late Ludlow, Late Silurian) age. These occurrences extend the biogeographical range of $R$. migrans from tropical to mid latitudes of the Early Palaeozoic Rheic Ocean in the palaeo-Southern Hemisphere, into subtropical regions of the palaeo-Northern Hemisphere on, or adjacent to, the Siberia Palaeocontinent. The new records reinforce the idea that $R$. migrans had wide dispersal capacity and probably possessed a pelagic lifestyle. It also endorses the use of $R$. migrans as a biostratigraphical marker fossil for the Ludfordian Stage, Ludlow Series, Upper Silurian.
\end{abstract}

KEYWORDS: myodocope ostracods, Late Silurian, Arctic Russia, biostratigraphy, palaeobiogeography

\section{INTRODUCTION}

Ostracods are a major group of small aquatic crustaceans and are by far the most prolific group of arthropods in the fossil record, ranging over some 500 million years from at least the Ordovician Period onward (Horne et al., 2002; Siveter, 2008; Williams et al., 2008). They are important components of freshwater, marine and brackish-water settings. Among ostracods, myodocopes were present and already diversified by the Silurian (Siveter et al., 2003, 2007, 2010, 2013). Although they are mostly nektobenthic, Recent myodocope ostracods are also an important component of marine zooplankton, ranging from the ocean 'Mixed Layer' to abyssal depths (Angel, 1993). Based on several lines of evidence, Siveter et al. (1991) proposed that myodocopes were pioneer ostracod zooplankton colonists, making the ecological shift from the benthos during the Silurian.

The first myodocope ostracod groups to colonize pelagic environments were probably the bolbozoids (e.g. Parabolbozoe bohemica (Barrande, 1872) and Bolbozoe anomala (Barrande, 1872)) and the cypridinids (e.g. Silurocypridina calva Perrier et al., 2011), which show a supposedly transoceanic distribution during the late Wenlock-early Ludlow interval (Perrier et al., 2011; Perrier \& Siveter, 2013). Richteria migrans (Barrande, 1872), one of the earliest 'entomozoid' ostracods (Perrier et al., 2007; Perrier, 2012) a group colloquially known as 'finger-print' ostracods because of their characteristic pattern of ribbed ornament - was also probably pelagic. 'Entomozoaceans' have particularly wide geographical distribution and biostratigraphical value in the Devonian and the Carboniferous, occurring, for example, in Europe, North Africa, North America and China (Gooday, 1983; Groos-Uffenorde \& Wang, 1989; Olempska, 2002a, b). Opinions differ regarding the lifestyle of the 'entomozoaceans'. Some authors consider that 'entomozoaceans' were benthic, possibly living in oxygen-depleted environments (Warshauer \& Duffield, 1983; Casier, 1987). However, it is generally thought that most members of the group occupied pelagic, perhaps mid-water niches (Gooday, 1983; Olempska, 1992; and references therein).

The biostratigraphical and palaeoecological significance of R. migrans were tested by Perrier et al. (2007), who showed that the species had wide distribution in the Silurian palaeo-Southern Hemisphere. This range is now extended for the first time into the palaeo-Northern Hemisphere based on new occurrences from the Silurian of Arctic Russia, from Kotel'ny Island and the Taimyr Peninsula, respectively.

\section{GEOLOGICAL SETTING}

$R$. migrans was found in Upper Silurian strata on Kotel'ny Island during an international expedition in 2011. Kotel'ny Island is the largest island of the Anjou group of the New Siberian Islands located between the Laptev Sea and the East Siberian Sea in the Russian Arctic (Fig. 1a, b). Kotel'ny Island is composed of tectonically deformed platform sequences that include all the systems of the Palaeozoic and Mesozoic eras, except for the Cambrian. The island is a tectonically controlled inlier within Precambrian basement, which includes a significant portion of the marine shelf of the Laptev and East Siberian seas (Natal'in et al., 1999; Kuzmichev \& Pease, 2007). Silurian strata are well exposed in the western part of the island (Fig. 1b). The Silurian rocks are up to $1050 \mathrm{~m}$ thick, consisting of carbonates and shales of the Urasin (Llandovery Series), Nikola (Wenlock-Ludlow Series) and Eselekh (Pridoli Series) formations (Sobolevskaya, 1976). The Urasin and Nikola formations are composed of predominantly black to darkgrey shales intercalated with thin beds of clayey limestones, whereas the Eselekh Formation is characterized by limestones.

$R$. migrans was recovered from black shales and associated limestone nodules of the Nikola Formation along the Chokurka $\left(75^{\circ} 26^{\prime} 43^{\prime \prime} \mathrm{N}, \quad 137^{\circ} 52^{\prime} 48^{\prime \prime} \mathrm{E}\right)$ and Tuor-Yuryakh $\left(75^{\circ} 18^{\prime} 75^{\prime \prime} \mathrm{N}\right.$, $\left.139^{\circ} 15^{\prime} 00^{\prime \prime} \mathrm{E}\right)$ river sections. Shales yield graptolites of the Saetograptus leintwardinensis Biozone, indicating strata assignable to the early Ludfordian Stage of the Ludlow Series (Sobolevskaya, 1976; Koren' \& Sobolevskaya, 1998; Suyarkova pers. comm. 2013) (Fig. 1d).

The material from the Taimyr Peninsula, Russia (Fig. 1a, c) was recovered from strata of Late Silurian age exposed along the right bank of the Nizhnyaya Taimyra River in the vicinity of Middendorf Cave (Fig. 1c, section P-90218). This outcrop was studied and sampled by AG during fieldwork carried out in 1990 


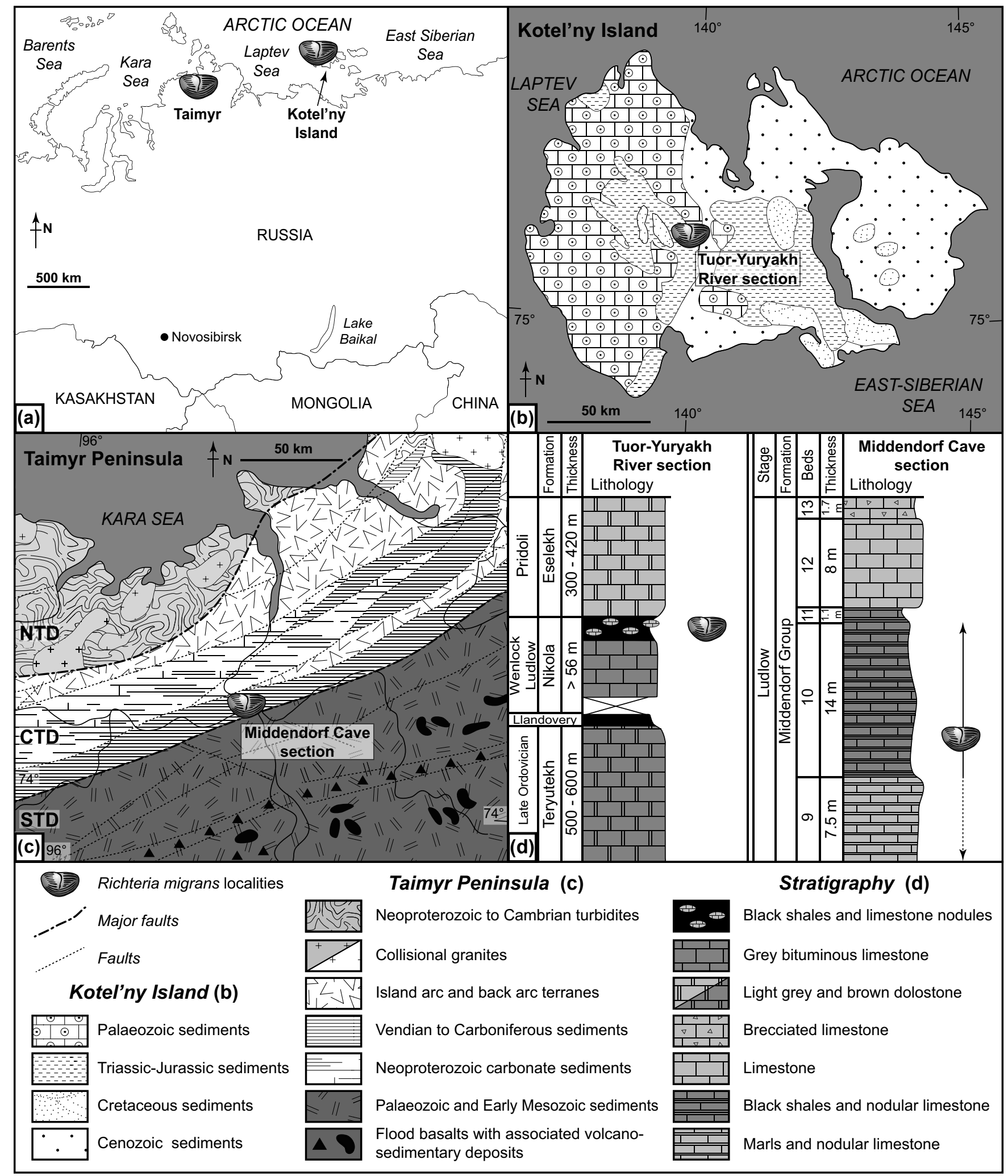

Fig. 1. Geological setting of localities for Richteria migrans. (a) Geographical position of the localities. (b) Geological map of Kotel'ny Island and location of the Tuor-Yuryakh River section. (c) Geological map of the Taimyr Peninsula and location of the Middendorf Cave section (NTD, CTD, STD denote North Taimyr Division, Central Taimyr Division and South Taimyr Division). (d) Sedimentological context of the Tuor-Yuryakh River and Middendorf Cave sections. Map of Kotel'ny Island after Kuzmichev (2009), Taimyr Peninsula after Metelkin et al. (2005). Section for the Taimyr Peninsula after Tesakov (2009); that for Kotel'ny Island after Kuzmichev (2009). 
by the Institute of Geology \& Geophysics, Novosibirsk. The Taimyr Peninsula lies between the Kara Sea and the Laptev Sea and contains igneous, metamorphic and sedimentary rocks of Proterozoic to Cretaceous ages. Taimyr has generally been divided into three east-west-trending zones, namely North, Central and South Taimyr (Fig. 1c). The Palaeozoic continental margin succession of Central Taimyr represents the stable platform sequence of the northern Siberia passive margin. Silurian strata are well exposed in Central Taimyr, consisting of carbonates and shales up to $500 \mathrm{~m}$ in thickness. Zlobin (1962), Tesakov et al. (1995) and Sobolevskaya et al. (1997) established a detailed bio- and lithostratigraphy for this area. The Silurian strata of Central Taimyr comprise the Dvoinaya and Middendorf groups (Tesakov et al., 1995), which are composed of predominantly black to dark-grey shales containing thin lenses and/or interbeds of black limestones. The limestones become thicker and more numerous up the succession.

R. migrans first appears in black mudstones with small micritic nodules in Bed 9 of the Middendorf Group, some $3.5 \mathrm{~m}$ above the cephalopod limestone of Bed 8, and is also common in Bed 10 (Bogolepova, 1994; Kříž \& Bogolepova, 1995) (Fig. 1d) of section P-90218 (75²0'31.36"N, 9949'52.83"E). Monograptus fritschi linearis was found in the black shales of Bed 9, indicating an early Ludfordian age (Kříž \& Bogolepova, 1995; Tesakov et al., 1995).

\section{MATERIAL AND METHODS}

The myodocopes consist of partially flattened and 3D-preserved specimens, now housed in the Palaeontological collections, Museum of Evolution, Uppsala University, Uppsala, Sweden, numbers PMU 27241-54. The morphological terminology for the myodocope valve follows that of Siveter et al. (1987). Rock matrix was removed from the specimens mechanically, using fine needles. Casts of the external moulds of ostracods were made using silicone rubber by the technique of Siveter (1982). Photographs were taken using a Leitz Aristophot mounted with a Canon EOS 5D camera, following the methods outlined in Siveter (1990).

\section{BIOSTRATIGRAPHICAL SIGNIFICANCE}

Perrier et al. (2007) proposed that $R$. migrans is a marker fossil for rocks of the lower and middle part of the Ludfordian Stage, Ludlow Series across Europe; this can now be extended into Arctic Russia, in the Nikola Formation of Kotel'ny Island and the Middendorf Group of the Taimyr Peninsula. R. migrans was previously recorded in the Kopanina Formation, Bohemia, Czech Republic (Perrier et al., 2007); the Long Mountain Siltstone Formation, Welsh basin, UK (Siveter, 2009); the La Lande-Murée and La Tavelle formations of the Armorican Massif and La Rouquette Formation of the Montagne Noire, France (Perrier et al., 2007); the Fluminimaggiore Formation, Sardinia (Perrier et al., 2007; Gnoli et al., 2009); the Niewachlów (Greywacke) Beds, Poland (Gürich, 1896); the Kurgan Horizon, north Nura-Tau Range, Uzbekistan (Mikhailova \& Siveter unpublished data, in Perrier et al., 2007) and possibly in the Ludlow Series of Germany (Perrier \& Siveter, 2013) and the Hemse Formation of Gotland (Hede, 1921) (Fig. 2a).

In the Czech Republic $R$. migrans ranges from the Monograptus fritschi linearis to Bohemograptus bohemicus s. 1. Interzone graptolite biozones (Perrier et al., 2007). In Britain it ranges from the Saetograptus leintwardinensis graptolite Biozone to the Bohemograptus proliferation interval (Siveter, 2009). The graptolites associated with some of the French and Sardinian occurrences of $R$. migrans are insufficiently studied or too illpreserved to provide precise independent stratigraphic control; however, based on the available geological information and its consistent stratigraphic range in the Czech Republic and Britain, Perrier et al. (2007) suggest a mid to late Ludlow Epoch age. Furthermore, although the Polish, central Asian, German and Swedish material remains unrevised, $R$. migrans was always recorded in these areas from the mid Ludlow Series.

The proposition of Perrier et al. (2007) that $R$. migrans can be used as a marker fossil for rocks assignable to the Ludfordian Stage of the Ludlow Series (Fig. 2a), is strengthened by the new records in the Kotel'ny Island (Ludfordian, Saetograptus leintwardinensis Biozone) and the Taimyr Peninsula (Ludfordian, Monograptus fritschi linearis Biozone).

\section{PALAEOGEOGRAPHICAL SIGNIFICANCE}

The widespread palaeogeographical distribution of $R$. migrans, in southerly tropical to mid latitudes on both sides of the Early Palaeozoic Rheic Ocean, was noted by Perrier et al. (2007). The new occurrences expand this distribution to the subtropical region of the palaeo-Northern Hemisphere on, or next to, the Siberia palaeocontinent (Fig. 2b). These new records therefore reinforce the idea that $R$. migrans had wide dispersal capacity.

The New Siberian Islands along with the western part of the East Siberian Sea belong to the New Siberian Islands microcontinent (Bogdanov et al., 1998; Kos'ko, 2007; Drachev, 2011; Cocks \& Torsvik, 2011; Vernikovsky et al., 2013). During the Late Silurian, the New Siberian Islands Terrane was located in northerly subtropical, $20-25^{\circ}$ latitudes. Cocks \& Torsvik (2011) placed the New Siberian Islands microcontinent between the Siberia palaeocontinent in the NE, the Kolyma-Omolon Terrane in the NW, and Baltica further south (Fig. 2b).

In contrast, based on palaeomagnetic data, Vernikovsky et al. (2013) and D.V. Metelkin (pers. comm.) place the New Siberian Islands north of the Chukotka Terrane, at about $45^{\circ} \mathrm{N}$ (Fig. 2b). However, this position seems unlikely because of the Siberian/ Baltic affinities of the New Siberian Islands trilobite fauna in Early Palaeozoic strata (Holm \& Westergaard, 1930; Danukalova et al., 2012), contrasting with the mix of Laurentian and Siberian faunas found in the Lower Palaeozoic of the Arctic AlaskaChukotka microcontinent (Cocks \& Torsvik, 2011).

The Taimyr Peninsula samples belong to the Central Taimyr Domain, a microplate that was accreted to the Siberian margin in the Late Neoproterozoic (c. 600Ma), and covered by Late Neoproterozoic (Vendian) and Palaeozoic successions (Vernikovsky, 1996; Vernikovsky et al., 2004). During the Late Silurian the Central Taimyr Domain was located in subtropical latitudes, at about $20^{\circ} \mathrm{N}$, on the southern part of the Siberia palaeocontinent (Metelkin et al., 2005; Cocks \& Torsvik, 2011) (Fig. 2b).

Our new observations confirm that, as noted by Perrier et al. (2007), the occurrences of $R$. migrans are always associated with either black micritic limestones (e.g. Kote'ny Island, Taimyr, Sardinia, Montagne Noire) or shales (e.g. Bohemia, Armorican Massif, central Asia). These lithologies contain cephalopod-, graptolite-, phyllocarid- and bivalve-dominated assemblages. The myodocope-bearing facies typify possible deep-shelf environments or topographic lows on the shelf (Siveter et al., 1991; Perrier et al., 2011) and are characterized by the lack of bioturbation, the 


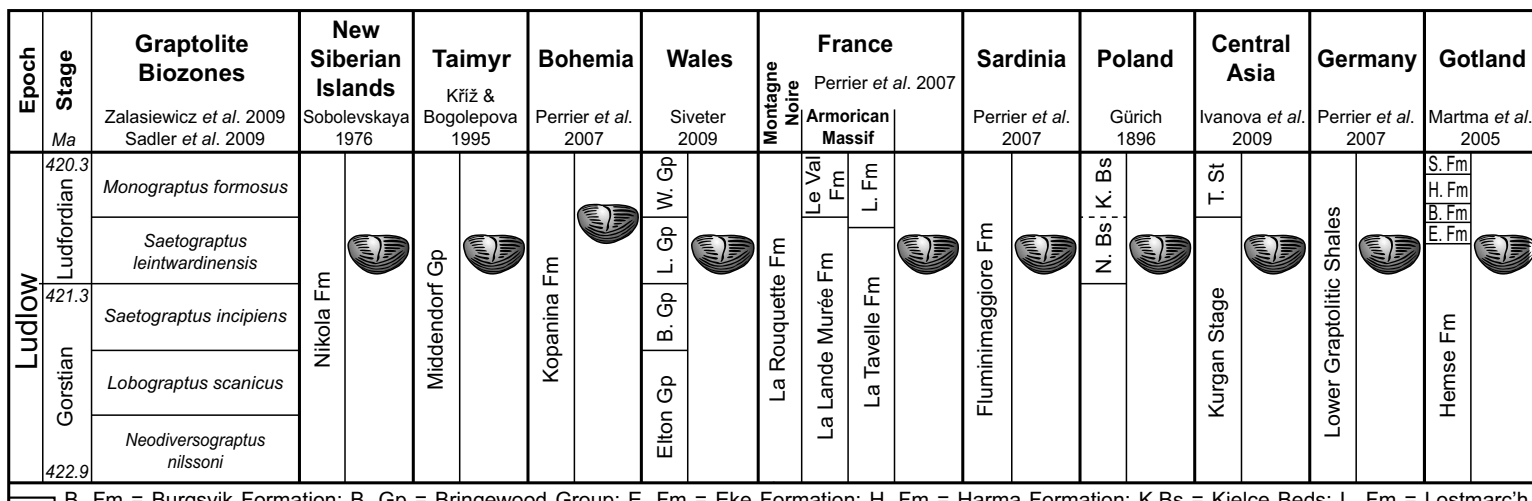

\begin{tabular}{l|l} 
(a) B. Fm = Burgsvik Formation; B. Gp = Bringewood Group; E. Fm = Eke Formation; H. Fm = Harma Formation; K.Bs = Kielce Beds; L. Fm = Lostmarc'h \\
Formation; L. Gp = Leintwardine Group; N. Bs = Niewachlów Beds; S. Fm = Sundre Formation; T. St = Tamchi stage; W. Gp = Whitcliffe Group.
\end{tabular}

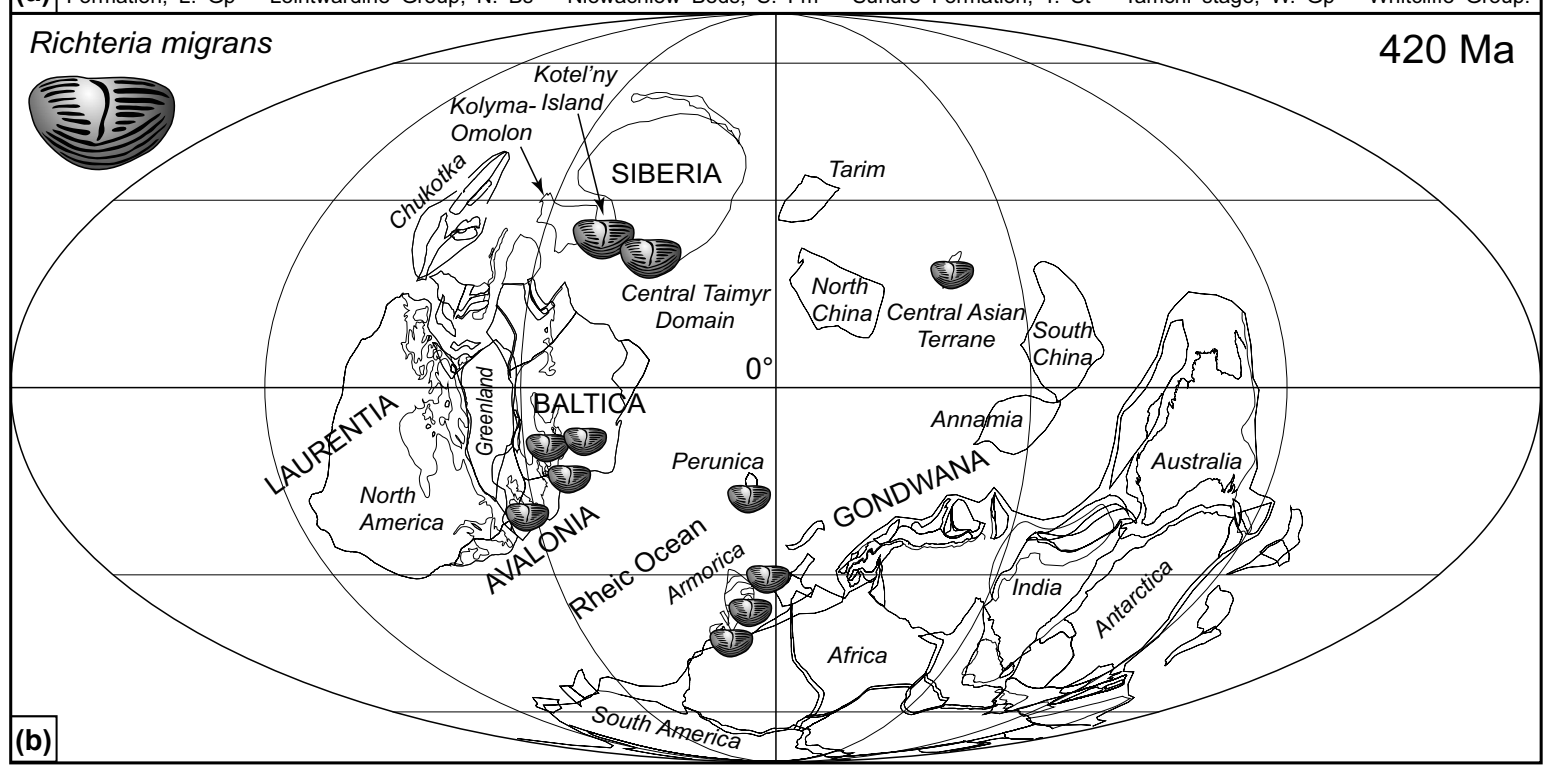

Fig. 2. Stratigraphic and palaeogeographical distribution of Richteria migrans: (a) stratigraphic position, which is approximate within each formation; (b) palaeogeographical distribution. In (b) the position of what is labelled central Asian terrane is not well constrained; it is based on the supposed Silurian location (in the vicinity of the South China and Tarim microcontinents; see Fortey \& Cocks, 2003) of various terranes that at the presentday lie immediately south of the 'Kazakh' terranes. The possible occurrence of $R$. migrans in the Ludlow Series of the Kellerwald, NE of Marburg, Germany, is tentatively plotted as if on Avalonia, but the palaeogeographical provenance is not well constrained. In the text we refer to the Monograptus fritschi linearis Biozone and this is the approximately equivalent biostratigraphical level to the Saetograptus leintwardinensis Biozone in Britain. Larger icons represent the new occurrences of R. migrans. Map after Torsvik (2009). Data from Gürich (1896), Ivanova et al. (2009), Kř́ž \& Bogolepova (1995), Martma et al. (2005), Perrier et al. (2007), Siveter (2009) and Sobolevskaya (1976).

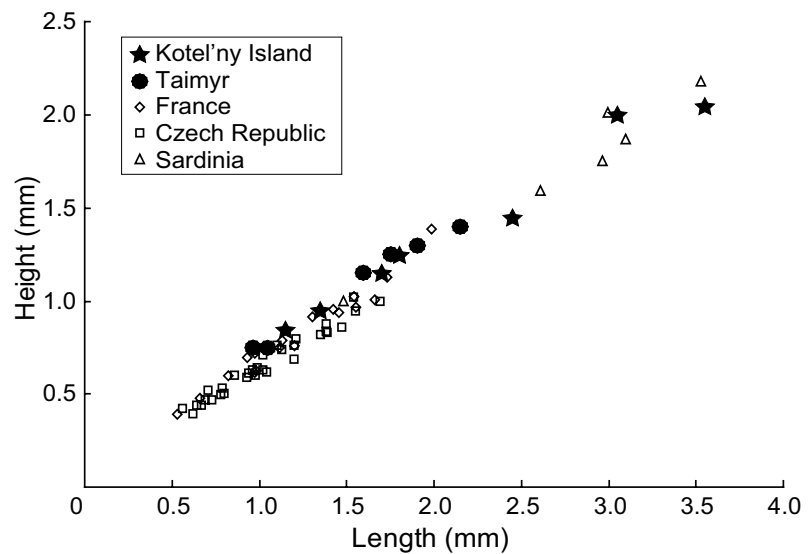

Fig. 3. Measurements of carapaces of Richteria migrans; specimens from France and the Czech Republic are after Perrier et al. (2007). presence of lamination and by a low diversity, mostly pelagic, fauna. These facies data, added to the cosmopolitan distribution, suggest that $R$. migrans probably possessed a pelagic lifestyle, and this is consistent with the timing of a proposed ecological shift in pioneer pelagic (myodocope) ostracods from benthic to pelagic modes of life during the late Early or early Late Silurian (see Siveter, 1984; Siveter et al., 1987, 1991; Siveter \& Vannier, 1990; Vannier \& Abe, 1992; Perrier et al., 2007, 2011).

\section{SYSTEMATIC PALAEONTOLOGY}

Order Myodocopida Sars, 1866 (nom. correct. Pokorný, 1953)

Family 'Entomozoidae' Přibyl, 1950 (= Entomidae Jones, 1873)

Remarks. For the complex nomenclatural status of the Entomozoacea, see Siveter \& Vannier (1990). 


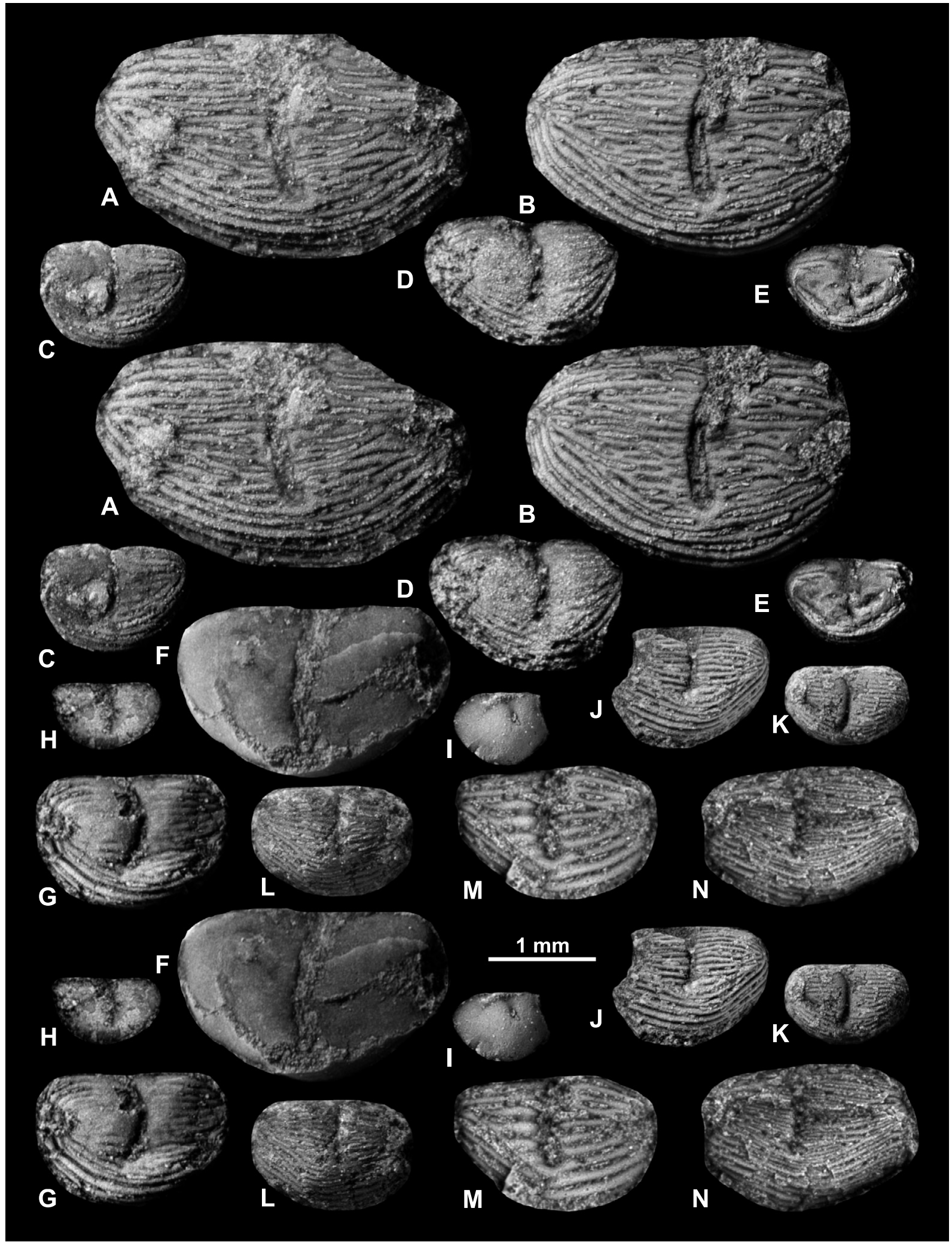

Explanation of Plate 1. Richteria migrans (Barrande, 1872), Ludlow Series, Silurian: figs A-G, Kotel'ny Island, New Siberian Islands, Russia; figs H-N, Taimyr Peninsula, Russia. A, right valve (PMU 27241); B, right valve (PMU 27242); C, left valve (PMU 27243); D, left valve (PMU 27244); E, right valve (PMU 27245); F, right valve, mould of the inner part of the carapace (PMU 27246); G, left valve (PMU 27247); H, left valve (PMU 27248); I, right valve (PMU 27249); J, left valve (PMU 27250); K, left valve (PMU 27251); L, right valve (PMU 27252); M, right valve (PMU 27253); N, left valve (PMU 27254). All pictures are lateral stereo-pairs. Figs A, D, M and N are silicone casts. 
Genus Richteria Jones, 1874

Richteria migrans (Barrande, 1872)

(Pl. 1, figs A-N; Fig. 3)

1995 'Entomis' aff. lamarmorai Canavari, 1900; Kř́ž \& Bogolepova: 580-581, pl. 70, fig. 12.

2003 Richteria migrans taimyrica Abushik, subsp. nov.; Abushik et al.: 122-123, pl. 27, figs 1-2.

2007 Richteria migrans (Barrande, 1872); Perrier et al.: 156-160, figs 6-10. (q.v. for full synonomy).

Material. More than 20 valves from the New Siberian Islands and 8 valves from the Taimyr Peninsula.

Dimensions. Maximum valve length - valve height of largest and smallest well-preserved specimens (Fig. 3): Kotel'ny Island: 3.552.05 mm (PMU 27241; Pl. 1, fig. A), 1.15-0.85 mm (PMU 27245; Pl. 1, fig. E); Taimyr: 2.15-1.40 mm (PMU 27254; Pl. 1, fig. N), 0.95-0.75 mm (PMU 27249; P1. 1, fig. I).

Distribution. Known from strata of Late Silurian age (Ludlow Epoch) of the Czech Republic, France, Sardinia, UK, Poland, Central Asia, Arctic Russia, and possibly Germany and Sweden.

Remarks. Based on what seems to be a more delicate ornament, Kř́ž \& Bogolepova (1995) assigned the Taimyr material to 'Entomis' aff. lamarmorai Canavari, 1900, and Abushik et al. (2003) created a new sub-species Richteria migrans taimyrica. Based on our evaluation of the global dataset of $R$. migrans, we consider this ornamental variation to be intraspecific (see Perrier et al., 2007). The largest Kotel'ny Island specimens are larger $(3.5 \mathrm{~mm}$ vs. $2 \mathrm{~mm})$ than those described by Perrier et al. (2007) from France and the Czech Republic, but of comparable size with the Sardinian specimens (Fig. 3).

\section{ACKNOWLEDGEMENTS}

This research was funded by a Leverhulme Trust foremost grant (RP14G0168). Fieldwork on the New Siberian Islands was funded by BP. OB thanks the consortium of oil and gas industry subscribers for its financial support of CASP work. This is a contribution to the International Geoscience Programme (IGCP) Project 591. The authors thank Prof. E. Olempska-Roniewicz and Dr H. GrossUffenorde for their reviews of the manuscript.

\section{Manuscript received 25 November 2013 \\ Manuscript accepted 5 January 2014 \\ Scientific Editing by Alan Lord}

\section{REFERENCES}

Abushik, A.I., Modzalevskaya, T.L., Tolmacheva, T.Y., Melnikova, L.M., Sobolev, N.N. \& Sobolevskaya, R.F. 2003. Atlas of the Palaeozoic Fauna of Taimyr, Part I, Brachiopods, Ostracods, Conodonts. VSEGEI, St Petersburg, 240pp. [In Russian.]

Angel, M.V. 1993. Marine planktonic ostracods: Keys and notes for identification of the species. Synopses of the British Fauna (New Series), 48. The Linnean Society of London and the Estuarine and Coastal Science Association, London, 1-416.

Barrande, J. 1872. Système Silurien du centre de la Bohème. 1. Prague and Paris, 647pp.

Bogdanov, N.A., Khain, V.E., Rosen, O.M. et al. 1998. Tectonic Map of the Kara and Laptev seas and North Siberia (scale 1:2 500 000). Federal Agency of cartography and geodesy, Moscow. [In Russian.]

Bogolepova, O.K. 1994. Cephalopod limestone biofacies: tajmyr (Eastern Siberia) - the Carnic Alps. In Schönlaub, H.P. \& Kreutzer, L.H. (Eds),
IUGS Subcommission on Silurian Stratigraphy, Field Meeting Eastern and Southern Alps, Austria, 30: Guidebook and abstract: 127.

Canavari, M. 1900. Fauna dei calcari nerastri con Cardiola ed Orthoceras di Xea San Antonio in Sardegna. Palaeontographica Italica, 5: 187-210.

Casier, J.G. 1987. Etude biostratigraphique et paléoécologique des ostracodes du récif de marbre rouge du Hautmont à Vodelée (partie supérieure du Frasnien, Bassin de Dinant, Belgique). Revue de Paléobiologie, 6: 193-204.

Cocks, L.R.M. \& Torsvik, T.H. 2011. The Palaeozoic geography of Laurentia and western Laurussia: a stable craton with mobile margins. Earth-Science Reviews, 201: 1-51.

Danukalova, M.K., Kuzmichev, A.B. \& Korovnikov, I.V. 2012. The Bennett "Terrane" in the Cambrian: a continuation of the Siberian Platform. In Sklyarov, E.V. (Ed.), Geodynamic lithosphere evolution of the Central Asian Belt (from ocean to continent), Irkutsk, Abstract volume 1: 73-75 [In Russian.]

Drachev, S.S. 2011. Tectonic setting, structure and petroleum geology of the Siberian Arctic offschore sedimentary basins. In Spencer, A.M., Embry, A.F., Gautier, D.L., Stoupakova, A.V. \& Sorensen, K. (Eds), Arctic Petroleum Geology. Geological Society of London, Memoirs, 35: 369-394.

Fortey, R.A. \& Cocks, L.R.M. 2003. Palaeontological evidence bearing on global Ordovician-Silurian continental reconstructions. Earth Science Reviews, 61: 245-307.

Gnoli, M., Perrier, V. \& Serventi, P. 2009. The state of research on Sardinian Silurian Crustacea. In Corradini, C., Ferretti, A. \& Storch, P. (Eds), The Silurian of Sardinia. Rendiconti della Societa Paleontologica Italiana, 3: 143-155.

Gooday, A.J. 1983. Entomozoacean Ostracods from the Lower Carboniferous of south-western England. Palaeontology, 26: 755-788.

Groos-Uffenorde, H. \& Wang, Shang-qi. 1989. The entomozoacean succession of South China and Germany (Ostracoda, Devonian). Courier Forschungsinstitut Senckenberg, 110: 61-79.

Gürich, G. 1896. Das Palaeozoicum im Polnischen Mittelgebirges. Verhandlungen der Russisch-kaiserlichen mineralogischen Gesellschaft zu St. Petersburg, Serie 2, 32: 1-539.

Hede, J.E. 1921. Gotlands Silurstratigrafi. Sveriges Geologiska Undersölkning, C291: 1-31.

Holm, G. \& Westergaard, A.H. 1930. A middle Cambrian fauna from Bennett Island. Notes of the Academy of Sciences of the USSR, Leningrad, series VIII, volume XXI, 8, 1-25 [In Russian.]

Horne, D.J., Cohen, A. \& Martens, K. 2002. Taxonomy, morphology and biology of Quaternary and Living Ostracoda. In Holmes, J.A. \& Chivas, A. (Eds), The Ostracoda: Applications in Quaternary Research. American Geophysical Union, Geophysical Monograph, 131, 5-36.

Ivanova, O., Owens, R.M., Kim, I. \& Popov, L.E. 2009. Late Silurian trilobites from the Nuratau and Turkestan ranges, Uzbekistan and Tajikistan. Geobios, 42: 715-737.

Jones, T.R. 1873. Notes on the Palaeozoic Bivalved Entomostraca (No. 10). Entomis and Entomidella. Annals and Magazine of Natural History, series 4: 413-417.

Jones, T.R. 1874. Über Entomis und ein neues Genus Richteria. Neues Jahrbuch für Mineralogie Geologie und Paläontologie, 2: 180. [In form of a letter to Prof. Geinitz; title given in the table of contents.]

Koren', T.N. \& Sobolevskaya, R.F. 1998. Silurian graptolites of Kotelnyi Island (Novosibirsk Islands): taxonomy and biostratigraphy. In GutierrezMarco, J.C. \& Rabano, I. (Eds), Proceedings 6th International Graptolite Conference (GWG-IPA) \& 1998 Field Meeting. IUGS Subcommission on Silurian Stratigraphy, Temas Geologico-Mineros ITGE, 193-197.

Kos'ko, M.K. 2007. Terranes of the East Arctic Russian Shelf. Doklady of the Russian Academy of Sciences, 231: 71-74. [In Russian.]

Kříž, J. \& Bogolepova, O.K. 1995. Cardiola signata community (Bivalvia) in Cephalopod limestones from Tajmyr (Gorstian, Silurian, Russia). Geobios, 28: 573-583.

Kuzmichev, A.B. 2009. Where does the South Anyui suture go in the New Siberian islands and Laptev Sea?: implications for the Amerasia basin origin. Tectonophysics, 463: 86-108. 
Kuzmichev, A.B. \& Pease, V.L. 2007. Siberian trap magmatism on the New Siberian Islands: constraints for Arctic Mesozoic plate tectonic reconstructions. Journal of the Geological Society, London, 164: 959-968.

Martma, T., Brazauskas, A., Kaljo, D., Kaminskas, D. \& Musteikis, P. 2005. The Wenlock-Ludlow carbon isotope trend in the Vidukle core, Lithuania, and its relations with oceanic events. Geological Quarterly, 49: 223-234.

Metelkin, D.V., Vernikovsky, V.A., Kazansky, A.Y., Bogolepova, O.K. \& Gubanov, A.P. 2005. Paleozoic history of the Kara microcontinent and its relation to Siberia and Baltica: paleomagnetism, paleogeography and tectonics. Tectonophysics, 398: 225-243.

Natal'in, B.A., Amato, J.M., Toro, J. \& Wright, J.E. 1999. Paleozoic Rocks of Northern Chukotka Peninsula, Russian Far East. Tectonics, 18, 977-1003.

Olempska, E. 1992. Shell structure of the entomozoaceans, allegedly planktonic ostracodes of the Palaeozoic. Acta Palaeontologica Polonica, 36: $373-398$.

Olempska, E. 2002a. The Late Devonian Upper Kellwasser Event and entomozoacean ostracods in the Holy Cross Mountains, Poland. Acta Palaeontologica Polonica, 47: 247-266.

Olempska, E. 2002b. Ontogeny and sexual dimorphism in the Middle Late Devonian rhomboentomozoid ostracod Franklinella. Journal of Micropalaeontology, 21: 9-16.

Perrier, V. 2012. An atypical Silurian myodocope ostracod from the Armorican Massif, France. Acta Palaeontologica Polonica, 57: 363373.

Perrier, V. \& Siveter, David J. 2013. The use of 'European' ostracode faunas in testing Silurian stratigraphy and palaeogeography. In Harper, D.A.T. \& Servais, T. (Eds), Early Palaeozoic Biogeography and Palaeogeography. Geological Society, London, Memoirs, 38: 347-356.

Perrier, V., Vannier, J. \& Siveter, David J. 2007. The Silurian pelagic myodocope ostracod Richteria migrans. Transactions of the Royal Society of Edinburgh, Earth Sciences, 98: 151-163.

Perrier, V., Vannier, J. \& Siveter, David J. 2011. Silurian bolbzoids and cypridinids (Myodocopa) from Europe: pioneer pelagic ostracods. Palaeontology, 54: 1361-1391.

Pokorný, V. 1953. A contribution to the taxonomy of the Palaeozoic ostracods. Sbornik Ustredniho ustavu geologickeho, Oddil geologicky, 20: $213-232$.

Přibyl, A. 1950. On the Bohemian Ostracoda of the families Entomozoidae and Entomoconchidae. Bulletin international de l'Académie tchèque des Sciences, 1949: 1-28.

Sadler, P.M., Cooper, R.A. \& Melchin, M. 2009. High resolution, early Paleozoic (Ordovician-Silurian) time scales. Geological Society of America Bulletin, 121: 887-906.

Sars, G.O. 1866. Oversigt af Norges marine Ostracoder. Norske Videnskcaps-Akademien Forhandlingar, 1865: 1-130.

Siveter, David J. 1982. Casts illustrating fine ornament of a Silurian ostracod. In Bate, R.H., Robinson, E. \& Sheppard, L.M. (Eds), Fossil and Recent Ostracods. British Micropalaeontological Society. Ellis Horwood, Chichester, 105-122.

Siveter, David J. 1984. Habitats and modes of life of Silurian ostracods. In Bassett, M.G. \& Lawson, J.D. (Eds), Autecology of Silurian Organisms. Special Papers in Palaeontology, 32: 71-85.

Siveter, David J. 2008. Ostracods in the Palaeozoic? Senckengergiana lethaea, 88: 1-9.

Siveter, David J. 2009. Silurian. In Whittaker, J.E.W. \& Hart, M.B. (Eds), Ostracods in British Stratigraphy. The Micropalaeontological Society, Special Publications, Geological Society, London, 45-90.

Siveter, David J. \& Vannier, J. 1990. The Silurian myodocope Entomozoe from the Pentland Hills, Scotland, its taxonomic, ecological and phylogenetic significance and the affinity of bolbozoid myodocopes. Transactions of the Royal Society of Edinburgh, Earth Sciences, 81: 71-76.

Siveter, David J., Vannier, J. \& Palmer, D. 1987. Silurian myodocopid ostracodes, their depositional environments and the origin of their shell microstructures. Palaeontology, 30: 783-813.
Siveter, David J., Vannier, J. \& Palmer, D. 1991. Silurian Myodocopes, Pioneer pelagic ostracods and the chronology of an ecological shift. Journal of Micropalaeontology, 10: 151-173.

Siveter, David J., Sutton, M.D., Briggs, D.E.G. \& Siveter, Derek J. 2003. An Ostracode crustacean with soft-parts from the Lower Silurian. Science, 302: 1749-1751.

Siveter, David J., Siveter, Derek, J., Briggs, D.E.G. \& Sutton, M.D. 2007. Brood care in a Silurian ostracod. Proceedings of the Royal Society of London, B, 274: 465-469.

Siveter, David J., Briggs, D.E.G., Siveter, Derek J. \& Sutton, M.D. 2010. An exceptionally preserved myodocopid ostracod from the Silurian of Herefordshire, UK. Proceedings of the Royal Society of London, B, 277: $1539-1544$

Siveter, David J., Briggs, D.E.G., Siveter, Derek J., Sutton, M.D. \& Joomun, S.C. 2013. A Silurian myodocope with preserved softparts: Cautioning the interpretation of the shell-based ostracod record. Proceedings of the Royal Society of London, B, 280, http://dx.doi. org/10.1098/rspb.2012.2664

Siveter, Derek J. 1990. Photography. In Briggs, D.E.G. \& Crowther, P.R. (Eds), Palaeobiology: A Synthesis. Blackwell, Oxford, 505-508.

Sobolevskaya, R.F. 1976. On the Ordovician and Silurian graptolites of the New Siberian islands. In Kaljo, D. \& Koren, T.N. (Eds), Graptolites and Stratigraphy. Academy of Sciences of Estonian SSR, Institute of Geology, Tallinn, 202-209 [In Russian.]

Sobolevskaya, R.F., Sobolev, N.N. \& Matveev, V.P. 1997. New stratigraphic divisions in Ordovician and Silurian of Taimyr. A collection of scientific articles. VNIIOkeangeologiya, St Petersburg, 7-12. [In Russian.]

Tesakov, Yu. I. 2009. Practice of the litho-, bio-, eco-, chronostratigraphic and biogeocenosis units' separation (on the example of the Silurian of East Siberia). News on Paleontology and Stratigraphy, 13, 15-128. [In Russian.]

Tesakov, Yu. I., Predtechensky, N.N., Berger, A.Ya., Khromykh, V.G., Kovalevskaya, E.O. \& Sobolev, N.N. 1995. Silurian stratigraphy of the Gorny Taimyr. In Malich, N.S. (Ed.), Details on Taimyr-land. VSEGEI, St Petersburg, 123-140. [In Russian.]

Torsvik, T.H. 2009. BugPlates software (IGCP 503). With reconstructions of Torsvik, T. H. and Cocks, L. R. M. (2002-2009). Statoil Hydro.

Vannier, J. \& Abe, K. 1992. Recent and early Palaeozoic myodocope ostracodes, functional morphology, phylogeny, distribution and lifestyles. Palaeontology, 35: 485-517.

Vernikovsky, V.A. 1996. The geodynamic evolution of Taimyr fold area. Geology of the Pacific Ocean, 12: 691-704. [In Russian.]

Vernikovsky, V.A., Vernikovskaya, A.E., Pease, V.L. \& Gee, D.G. 2004. Neoproterozoic Orogeny along the margins of Siberia. In Gee, D.G. \& Pease, V. (Eds), The Neoproterozoic Timanide Orogen of Eastern Baltica. Geological Society, London, Memoirs, 30: 233-247.

Vernikovsky, V.A., Metelkin, D.V., Tolmacheva, T.Y., Malyshev, N.A., Petrov, O.V., Sobolev, N.N. \& Matushkin, N.Y. 2013. Concerning the issue of paleotectonic reconstructions in the Arctic and of the tectonic unity of the New Siberian Islands terrane: New paleomagnetic and paleontological data. Doklady Earth Sciences, 451: 791-797.

Warshauer, S.M. \& Duffield, S.L. 1983. The paleoecology of Devonian entomozoid ostracodes in the subsurface of the Appalachian Basin. In Krstic, N. (Ed.), Taxonomy, biostratigraphy and distribution of Ostracodes. Proceedings of the 7th International Symposium on Ostracoda, Serbian Geological Society, Belgrade, 157-161.

Williams, M., Siveter, David J., Salas, M.J., Vannier, J., Popov, L.E. \& Ghobadi Pour, M. 2008. The earliest ostracods: The geological evidence. Senckenbergiana lethaea, 88, 11-21.

Zalasiewicz, J.A., Taylor, L., Rushton, A.W.A., Loydell, D.K., Rickards, R.B. \& Williams, M. 2009. Graptolites in British stratigraphy. Geological Magazine, 146, 785-850

Zlobin, M.N. 1962. The Silurian and Devonian deposits of eastern Taimyr. NIGA, 130, 27-36. [In Russian.] 


\section{TAKE THAT NEXT STEP TO FAST TRACK YOUR CAREER...BECOME A CHARTERED GEOLOGIST OR CHARTERED SCIENTIST}

- A peer reviewed process which requires a high standard of knowledge, competence and professionalism

- The hallmark of professional achievement, recognised in the UK and in an expanding number of countries

- Identifies you as competent and professional in your chosen speciality, and binds you to an enforced Code of Conduct

- $\quad$ Recognises your achievement within your industry and among your peers

- In some sectors Chartered Geologists can sign off legal papers and reports

- Chartered Geologist makes you eligible to apply for the title of European Geologist
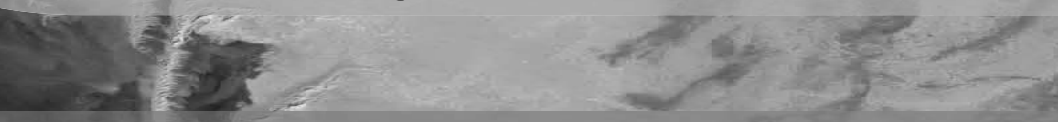

Contact us today and request an information pack to charter your flight to success

www.geolsoc.org.tik/chaptership

Fellowship Department, The Geological Society, Burlington House, Piccadilly, London W1J OBG

Tel: 02074349944 Fax: 02074398975

Email: 